\title{
Crystal Growth and Some Ferroelectric Properties of Tungsten-Bronze Type Niobates $\mathbf{B a}_{2} \mathbf{N a}_{1-x} \mathbf{L} \mathbf{i}_{x} \mathbf{N b}_{5} \mathbf{O}_{15}$
}

\author{
By \\ Yoichiro MASUDA and Masanobu WADA* \\ (Department of Electrical Engineering, Hachinohe Institute of Technology, Department \\ of Electronics Engineering, Faculty of Engineering, Tohoku University*)
}

\section{Introduction}

Recently, there have come to be required optical elements which suffer no optical damage even for particularly powerful laser beam and also have powers for efficient modulation and multiplication. There are tungsten-bronze type (T.B) oxides having oxygen octahedron structure which meet the requirements.

T.B type transparent ferroelectric oxide has excellent properties for a high electro-optical effect and a high non-linear optical effect such as Second Harmonic Generation (SHG), but the reproductibility in growing crystals is poor. Using the melting method, the present authors have grown T.B type $\mathrm{Ba}_{2} \mathrm{Na}_{1-x} \mathrm{Li}_{x} \mathrm{Nb}_{5} \mathrm{O}_{15}$ ferroelectric single crystals and obtained some results concerning ferroelectric properties.

\section{Crystal Growth}

E.A Giess et al. ${ }^{1)}$ have reported the phase relation of $\mathrm{BaO}-\mathrm{Na}_{2} \mathrm{O}-\mathrm{Nb}_{2} \mathrm{O}_{5}$ ternary system and the crystal growth from melts. Further, they have tried to grow T.B type $\mathrm{Ba}_{2} \mathrm{Na}_{1-x} \mathrm{~K}_{x} \mathrm{Nb}_{5} \mathrm{O}_{15}{ }^{2)}$ single crystals from the composition of $15\{(x)$ $\left.\mathrm{K}_{2} \mathrm{O}+(1-x) \mathrm{Na}_{2} \mathrm{O}\right\}+37.5 \mathrm{BaO}+47.5 \mathrm{Nb}_{2} \mathrm{O}_{5}, \quad \mathrm{~A}$ $\mathrm{Ba}_{2} \mathrm{NaNb}_{5} \mathrm{O}_{45}$ (BNN) single crystal has a high rate of growth toward $c$-axis and is liable to grow in the form of needle. The authors paid their attention to the compositions $15\left\{(x) \mathrm{Li}_{2} \mathrm{O}+\right.$ $\left.(1-x) \mathrm{Na}_{2} \mathrm{O}\right\}+37.5 \mathrm{BaO}+47.5 \mathrm{Nb}_{2} \mathrm{O}_{5}$ and have grown the crystals of three kinds of composition, $x=0,0.2$ and 0.4 . The raw materials are $\mathrm{Li}_{2} \mathrm{CO}_{3}$ (Kanto Chemical Co.), $\mathrm{Na}_{2} \mathrm{CO}_{3}$ (Kanto Chemical Co.), $\mathrm{BaCO}_{3}$ (Kanto Chemical Co.) and $\mathrm{Nb}_{2} \mathrm{O}_{5}$ (Mitsui Metal Co. for optical grade) which are the guaranteed grade of reagents. Mixtures of required amount of each composition were pressed into a size of disk to be $20 \mathrm{~mm}$ in diameter and $1 \mathrm{~mm}$ in thickness, (under the pressure of about $1 \mathrm{t} / \mathrm{cm}^{2}$ ) and calcined at $1000^{\circ} \mathrm{C}$ for two hours. A $50 \mathrm{ml}$ platinum crucible was filled with 70 grams of the powder of the calcined disk and heated in an electric furnace. The furnace chamber was heated at the heating rate of $200^{\circ} \mathrm{C} / \mathrm{h}$, until the temperature of about $100^{\circ} \mathrm{C}$ higher than the melting point. Then the highest temperature was kept in the furnace chamber for 3 to 4 hours. After soaking, the chamber was slowly cooled at the cooling rate of 5 to $10^{\circ} \mathrm{C} / \mathrm{h}$. Concerning the habit of as grown crystal, the crystal for $x=0$ was needle-like and the ones for $x=0.2$ and 0.4 were block-like.

The crystal $(x=0.2)$ obtained was transparent and about 10 to $20 \mathrm{~mm}$ in one side, having (001) plane parallel to the growing surface as shown in Fig. 1.

Pale blue-colored crystal and yellowish flux

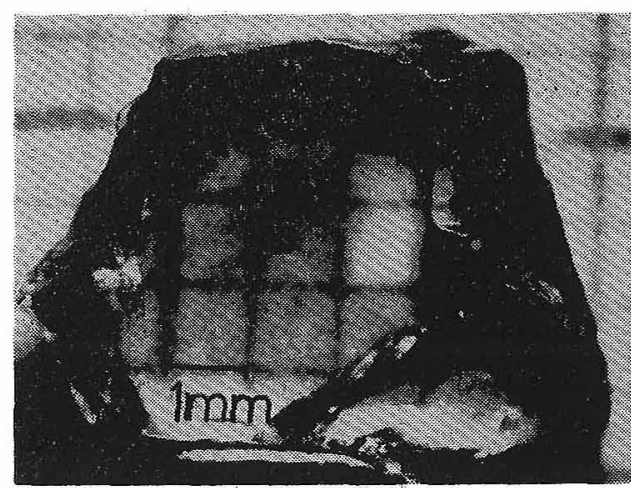

Fig. 1. As-grown single crystal of $\mathrm{Ba}_{2} \mathrm{Na}_{0,8} \mathrm{Li}_{0.2} \mathrm{Nb}_{5} \mathrm{O}_{15}$.

Table 1. Results of crystal growth.

\begin{tabular}{ccccccc}
\hline $\begin{array}{c}\text { Composition } \\
(x)\end{array}$ & $\begin{array}{c}\text { Charged } \\
\text { weight } \\
(\mathrm{g})\end{array}$ & $\begin{array}{c}\text { Weight of } \\
\text { after melt } \\
(\mathrm{g})\end{array}$ & $\begin{array}{c}\text { Evaporated } \\
\text { loss } \\
(\%)\end{array}$ & $\begin{array}{c}\text { Melting } \\
\text { point } \\
\left({ }^{\circ} \mathrm{C}\right)\end{array}$ & $\begin{array}{c}\text { Habit of } \\
\text { crystal }\end{array}$ & $\begin{array}{c}\text { Color of as-grown } \\
\text { crystal }\end{array}$ \\
\hline 0 & 70.84 & 68.15 & 2.38 & 1480 & needle & white \\
0.2 & 73.55 & 71.15 & 3.26 & 1450 & block & white + blue \\
0.4 & 70.53 & 68.29 & 1.75 & 1380 & block & white + blue \\
\hline
\end{tabular}


were co-existed with block-like transparent crystal. When the co-existing pale blue colored crystal were annealed in air at about $1000^{\circ} \mathrm{C}$ for two hours, the color dismissed.

So this coloration may have been caused by the vacancy of oxygen.

As shown in Table 1 , the materials charged in a crucible were lost by 2 to $3 \%$ during the growth via evaporation. The melting temperature in Table 1 decreases with increasing $\mathrm{Li}_{2} \mathrm{O}$.

\section{Chemical analysis}

Table 2 shows the results of chemical analysis of three samples

Table 2. Results of chemical analysis before and after crystallization of $\mathrm{Ba}_{2} \mathrm{Na}_{1-x} \mathrm{Li}_{x} \mathrm{Nb}_{5} \mathrm{O}_{15}$ compound.

\begin{tabular}{llll}
\hline $\begin{array}{c}\text { Chemical formula of } \\
\text { starting material }\end{array}$ & $\mathrm{Li} / \mathrm{Na}$ & $\begin{array}{l}\text { Chemical formula of } \\
\text { as-grown crystal }\end{array}$ & $\mathrm{Li} / \mathrm{Na}$ \\
\hline $\mathrm{Ba}_{3.947} \mathrm{Na}_{2.105} \mathrm{Nb}_{10} \mathrm{O}_{30}$ & 0 & $\mathrm{Ba}_{3.89} \mathrm{Na}_{2.51} \mathrm{Nb}_{9.94} \mathrm{O}_{80}$ & 0 \\
$\mathrm{Ba}_{8.947} \mathrm{Na}_{1.684} \mathrm{Li}_{0.421} \mathrm{Nb}_{10} \mathrm{O}_{30}$ & 0.251 & $\mathrm{Ba}_{3.75} \mathrm{Na}_{8.84} \mathrm{Li}_{2.16} \mathrm{Nb}_{9.30} \mathrm{O}_{30}$ & 0.56 \\
$\mathrm{Ba}_{3.947} \mathrm{Na}_{1.263} \mathrm{Li}_{0.842} \mathrm{Nb}_{10} \mathrm{O}_{30}$ & 0.672 & $\mathrm{Ba}_{4.01} \mathrm{Na}_{1.89} \mathrm{Li}_{1.44} \mathrm{Nb}_{9.73} \mathrm{O}_{30}$ & 0.76 \\
\hline
\end{tabular}

Suppose that the reaction formula in the experiment is generally indicated in the following formula.

$$
\begin{aligned}
& 15(x) \mathrm{Li}_{2} \mathrm{O}+15(1-x) \mathrm{Na}_{2} \mathrm{O}+37.5 \mathrm{BaO} \\
&+ 47.5 \mathrm{Nb}_{2} \mathrm{O}_{5} \\
& \rightleftharpoons 9.5 \mathrm{Ba}_{3.9447}\left(\mathrm{Li}_{x} \mathrm{Na}_{1-x}\right)_{2.1053} \mathrm{Nb}_{10} \mathrm{O}_{30} \\
&+5\left(\mathrm{Li}_{x} \mathrm{Na}_{1-x}\right) \mathrm{O} .
\end{aligned}
$$

The atomic ratio was $\mathrm{Li} / \mathrm{Na}=0.25$ in the charged material for the sample $x=0.2$, but the chemically analyzed value of $\mathrm{Li} / \mathrm{Na}$ was 0.563 in the resultant crystal. While for $x=0.4$, the charged ratio was $\mathrm{Li} / \mathrm{Na}=0.67$ and the analyzed ratio was $\mathrm{Li} / \mathrm{Na}=0.76$, slightly bigger than the charged ratio. From this, it follows that a crystal which

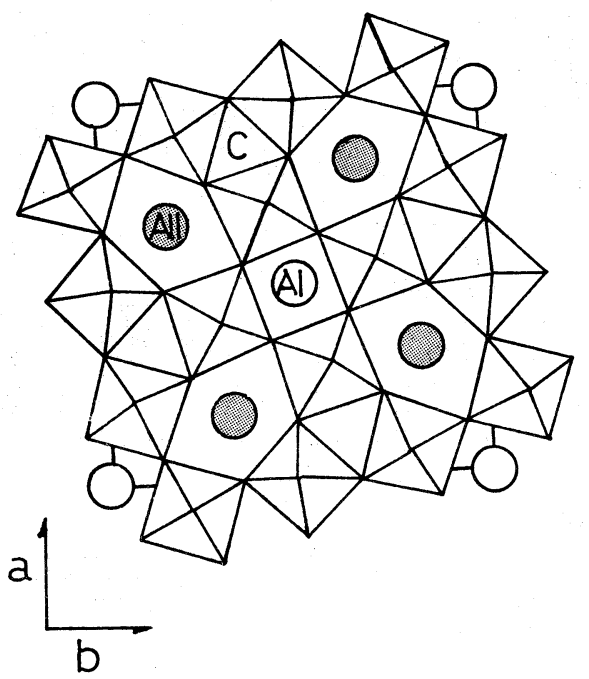

Fig. 2. Schematic picture of tetragonal tungsten-bronze unit cell. is about the same in composition as the charged amount, is formed for the composition of $x=0.4$. This analyzed value was calculated on the basis of a supposition that oxygen is distributed in an ideal condition.

\section{Crystal structure}

Figure 2 shows a schematic picture ${ }^{4}$ of T.B type structure obtained by projecting the (001) plane. If the ions which can go into the cages in the structure are shown in AI, AII, and C and the ions occupying the center of oxygen octahedron in $\mathrm{BI}$ and $\mathrm{BII}$, the general formula of T.B structure is given in $\left\{(\mathrm{AI})_{2}(\mathrm{AII})_{4} \mathrm{C}_{4}\right\}$ $\left\{(\mathrm{BI})_{2}(\mathrm{BII})_{8}\right\} \mathrm{O}_{30}$.

The structure in which the position of $\mathrm{AI}$ and AII are occupied by 6 cations is called the filled in type T.B structure, and the structure in which the position of $\mathrm{AI}$ and AII including $\mathrm{C}$ position are occupied by 10 cations, is called the perfect filled in T.B structure (the typical example is $\mathrm{K}_{6} \mathrm{Li}_{4} \mathrm{Nb}_{10} \mathrm{O}_{30}$ ).

Now, using a conoscope, isogyer on the (001) plane of the sample of $x=0.2$ obtained was observed. The observation showed that the sample is a biaxial crystal with very small $2 \mathrm{~V}$ (the angle between the optical axes).

The powder X-ray diffraction patterns obtained by using $\mathrm{CuK}_{\alpha}$ radiation, showed that the sample is an orthorhombic system in which $a$-axis is nearly equal to $b$-axis at room temperature. A Laue pattern of (001) plane photographed by the permeation method shows the fourth symmetry.

Lattice parameters were determined by the powder method with a silicon internal standard on using $\mathrm{CuK}_{\alpha}$ radiation. The measured Bragg angle were (840), (480) and (004). The obtained lattice parameters are $a_{0}=17.47_{3} \AA, \quad b_{0}=17.48_{0} \AA$ and $c_{0}=9.50_{3} \AA$.

\section{Ferroelectric properties}

Most of T.B type crystals are considered to come under the displacive type ferroelectric. On the surface of the crystal $(x=0.2)$ of $3 \times 5 \times 2$ $\mathrm{mm}^{3}$ in dimension, Au film was evaporated as an electrode for dielectric measurement. Fig. 3 shows the temperature dependence of $\varepsilon_{33}{ }^{T}$ and $\varepsilon_{11}{ }^{T}$ obtained by using an universal bridge of $1 \mathrm{kHz}$. The value of $\varepsilon_{33}{ }^{T}$. was about 60 at room temperature and that of $\varepsilon_{11}{ }^{T}$ was $180 . \varepsilon_{33}{ }^{T}$ was about 1500 and $\varepsilon_{11}{ }^{T}$ was 360 at Curie point of $490^{\circ} \mathrm{C}$.

According to S. Singh et al. ${ }^{3)}$, the Curie point of pure $\mathrm{Ba}_{2} \mathrm{NaNb}_{5} \mathrm{O}_{15}(\mathrm{BNN})$ is at about $580^{\circ} \mathrm{C}$ and $\varepsilon_{33}{ }^{T}$ is about 24,000 at the Curie point.

The value of $\varepsilon_{33}{ }^{T}$ was $1 / 16$ of the value of $\mathrm{BNN}$. On the other hand, no dielectric anomalies were recognized in the vicinity of $260^{\circ} \mathrm{C}$ 


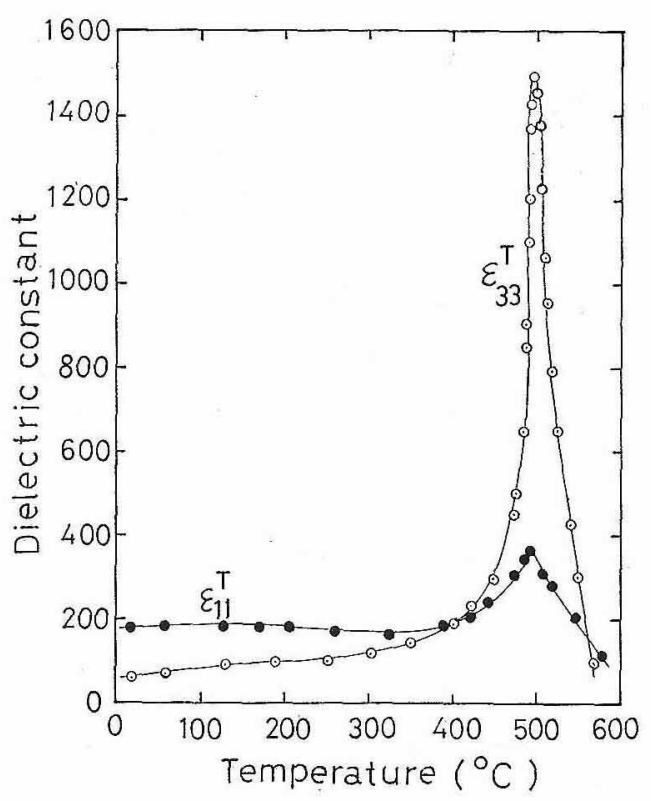

Fig. 3. Dielectric constant $\varepsilon_{11}{ }^{T}$ and $\varepsilon_{33}{ }^{T}$ as function of temperature $(x=0.2)$.

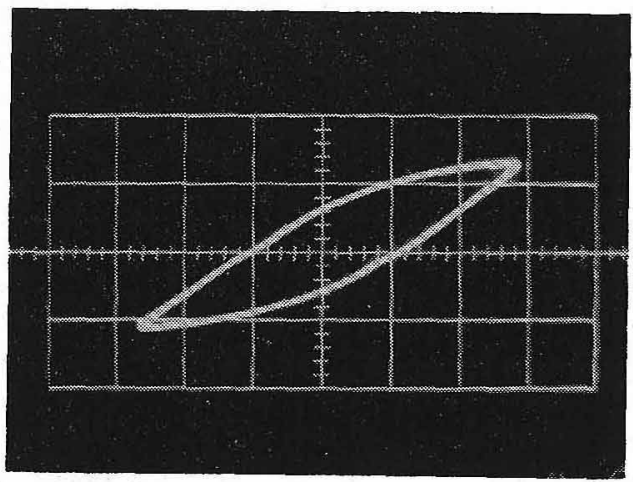

(a) $P_{r 3}=2.3 \mu \mathrm{C} / \mathrm{cm}^{2}$ $E_{c 3}=1400 \mathrm{~V} / \mathrm{mm}$ at $25^{\circ} \mathrm{C}$

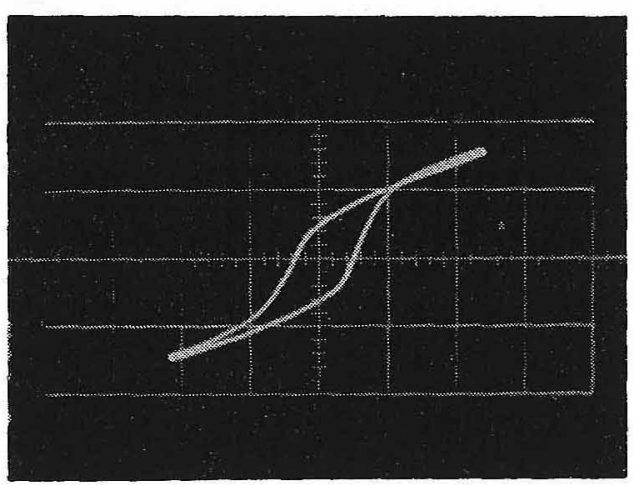

(b) $R_{r 3}=21 \mu \mathrm{C} / \mathrm{cm}^{2}$ $E_{c 8}=640 \mathrm{~V} / \mathrm{mm}$ at $105^{\circ} \mathrm{C}$

Fig. 4. $D-F$ hysteresis loops of $\mathrm{Ba}_{2} \mathrm{Na}_{0.8} \mathrm{Li}_{0.2} \mathrm{Nb}_{5} \mathrm{O}_{15}$ single crystal at $25^{\circ} \mathrm{C}$ and $105^{\circ} \mathrm{C}$. which correspond to the crystallographic transition; orthorhombic system $\rightleftharpoons$ tetragonal system. The Curie Weiss constant was about $1.5 \times 10^{5 \circ} \mathrm{K}$. The value is about the same as the ones of $\mathrm{BNN}$.

Fig. 4 shows the $D-E$ hysteresis loops of a sample $(x=0.2)$ of $2 \times 4 \times 1 \mathrm{~mm}^{3}$ in size, measured with a Sowyer-Tower circuit at $50 \mathrm{~Hz}$.

Some T.B type oxide having ferroelectric properties showed spontaneous polarization $\left(P_{s}\right)$ parallel to $c$-axis. The measurement of $D-E$ hysteresis loop of this crystal revealed also spontaneous polarization along $c$-axis.

The hysteresis loop showed that the value of coercive force $\left(E_{c 3}\right)$ was $1400 \mathrm{~V} / \mathrm{mm}$ and the polarization was unsaturated at $20^{\circ} \mathrm{C}$. The remnant polarization $\left(P_{r 3}\right)$ was as small as $2.3 \mu \mathrm{C} / \mathrm{cm}^{2}$. When the measurement was made in silicon oil at $105^{\circ} \mathrm{C}$, the coercive force $\left(E_{c 3}\right)$ reduced to 640 $\mathrm{V} / \mathrm{mm}$ and $P_{r 3}$ showed the value of $21 \mu \mathrm{C} / \mathrm{cm}^{2}$, which is close to the saturation value.

Abrahams ${ }^{5}$ induced $P_{s}=1.8 \sqrt{T_{c}}\left(\mu \mathrm{C} / \mathrm{cm}^{2}\right)$ as the empirical law from the values between the saturated polarization $\left(P_{s}\right)$ and $T_{c}$ of perovskite type and T.B type displacive ferroelectrics.

According to this empirical law, the spontaneous polarization can be known by measuring the Curie temperature of the ferroelectrics. But in the crystals of $\mathrm{BNN}$ and $\mathrm{Ba}_{2} \mathrm{Na}_{0.8} \mathrm{Li}_{0.2} \mathrm{Nb}_{5} \mathrm{O}_{15}$ considerably low $P_{s}$ values were obtained in the actual measurements. The reason why the actually measured value of $P_{s}$ is lower than the value expected in the empirical law is not known and this subject has yet to be studied further in detail.

Fig. 5 shows the multidomain structure of an optically polished crystal $(x=0.2)$ of about 0.3 $\mathrm{mm}$ in thickness observed under the crossed nicols.

Fig. 6 and 7 show the etching patterns of a single crystal subjected to etching for fifteen minutes in hot hydrogen fluoride.

Fig. 6 is an etching surface of (100) plane having pits of 5 to $6 \mu \mathrm{m}$ in one side. Square pits

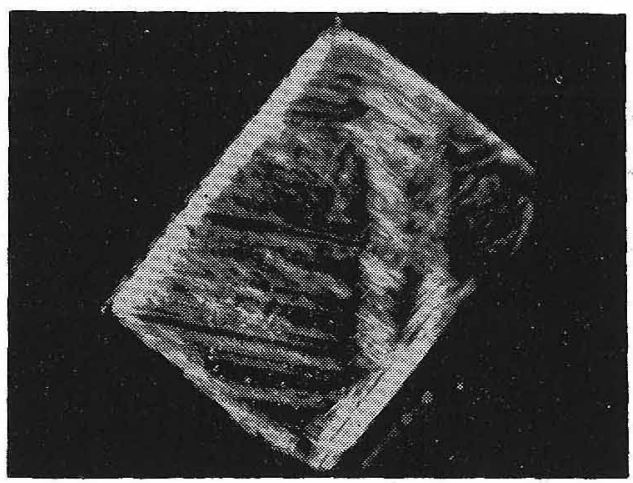

Fig. 5. A photograph of the ferroelectric $180^{\circ}$ multi-domain structure $(x=0.2)$. 

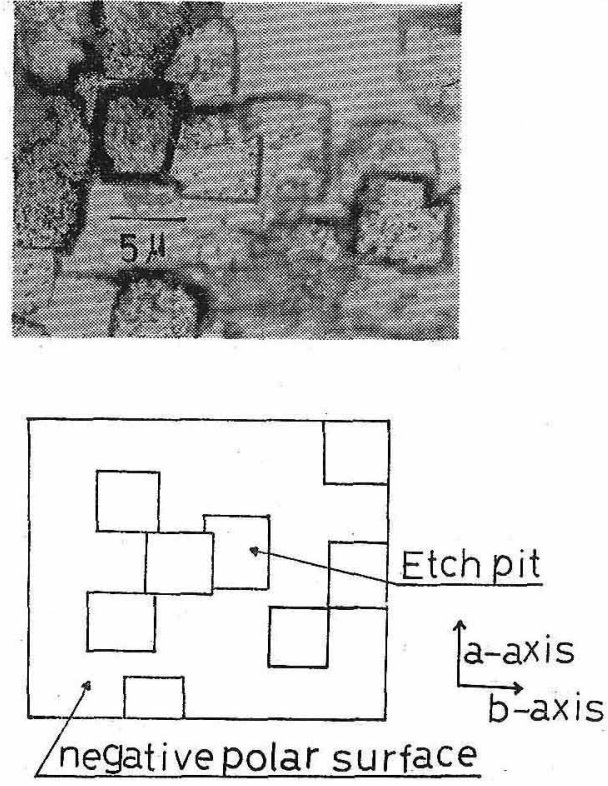

Fig. 6. A etching pattern on the negative polar surface of single domain $(x=0.2)$.

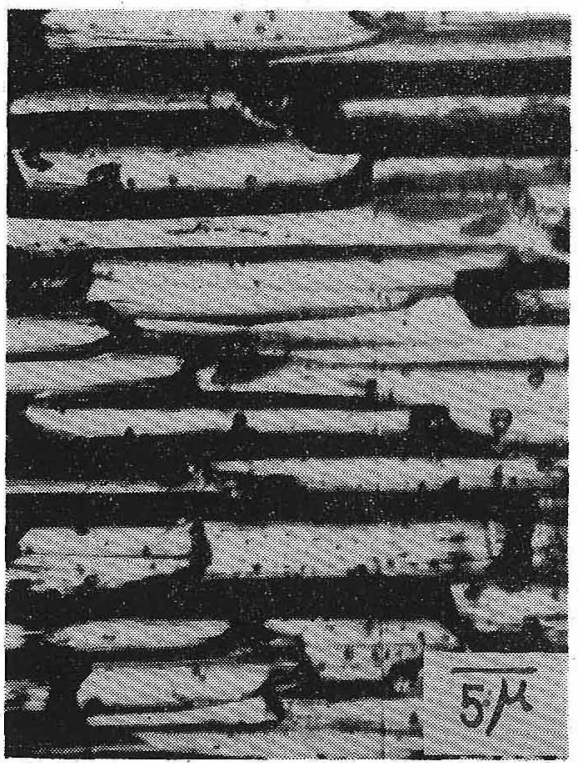

Fig. 7. A etching pattern of (100) plane $(x=0.2)$.

are shown on the negative plane. The sides of pits are in accordance with extinction position, this direction coincides with the main axes $\left(a_{0}\right.$ and $b_{0}$ axes)

Fig. 7 is an etching surface of (100) plane. The long and slender pit was about $1.5 \mu \mathrm{m}$ in width. Further, an observation was made on the surface of crystal with single domain obtained by apply. ing an electric field of $3500 \mathrm{~V} / \mathrm{mm}$ for two hours in silicon oil of about $200^{\circ} \mathrm{C}$.

Then it was etched. The observation showed

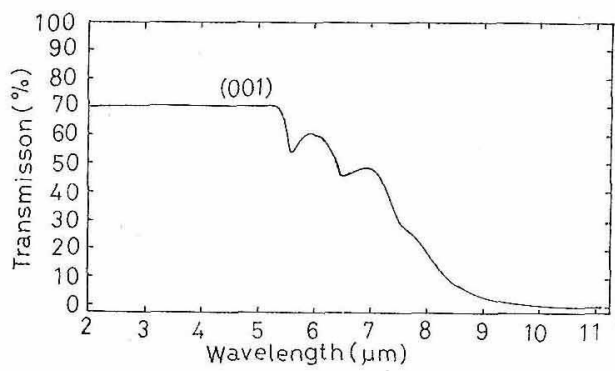

Fig. 8. Absorption spectrum as function of wave length $(x=0.2)$.

that square pits obviously appeared on the negative surface, but not on the positive surface.

\section{Optical properties}

Fig. 8 shows the transmission of a sample of $x=0.2$, for $5 \times 5 \times 0.3 \mathrm{~mm}^{3}$ in size with optically polished (001) plane. Two absorptions are observed at $5.5 \mu \mathrm{m}$ and $6.5 \mu \mathrm{m}$.

\section{Summary}

1) Single crystals with three compositions of $x=0,0.2$ and 0.4 for $15(x) \mathrm{Li}_{2} \mathrm{O}+15(1-x) \mathrm{Na}_{2} \mathrm{O}$ $+37.5 \mathrm{BaO}+47.5 \mathrm{Nb}_{2} \mathrm{O}_{5}$ were grown at the temperatures ranging from $1550^{\circ} \mathrm{C}$ to $1200^{\circ} \mathrm{C}$ at the cooling rate of 5 to $10^{\circ} \mathrm{C} / \mathrm{h}$ in an electric furnace.

For the composition of $x=0$, a needle-like crystal was obtained, and from the compositions of $x=$ 0.2 and 0.4 , block-like transparent crystals of about 10 to $20 \mathrm{~mm}$ in one side were obtained. In addition, a pale blue crystal and pale yellow flux were found to co-exist in as grown condition in a crucible.

2) The Curie point $T_{c}=490^{\circ} \mathrm{C}$ was obtained from the temperature where the dielectric peaks $\varepsilon_{11}{ }^{T}=360$ and $\varepsilon_{33}{ }^{T}=1500$ appeared. The dielectric constants at room temperature were $\varepsilon_{11}{ }^{T}=180$ and $\varepsilon_{33}{ }^{T}=60$. The anisotropy in the dielectric constant was about 3 times along the $a$-axis than $c$-axis.

3) The coercive force $\left(E_{c 3}\right)$ obtained by using the Sowyer-Tower circuit at $50 \mathrm{~Hz}$ was $1400 \mathrm{~V} / \mathrm{mm}$ at $20^{\circ} \mathrm{C}$ and the polarization was unsaturated, giving $P_{r 3}=2.3 \mu \mathrm{C} / \mathrm{cm}^{2}$, but at $105^{\circ} \mathrm{C}, E_{c 3}$ reduced to $640 \mathrm{~V} / \mathrm{mm}$ and the polarization became $21 \mu \mathrm{C} / \mathrm{cm}^{2}$, which was close to saturation.

This value is much lower than the value $P_{s}=$ $1.8 \sqrt{T_{c}}$ expected from the empirical law by Abraham. Also it was confirmed that $P_{s}$ is in the direction of (001) axis.

4) An observation of ferroelectric $180^{\circ}$ multidomain structure was made under crossed nicols.

The multidomain was observed as the contrast between light and shade which were in accordance with the positive and negative planes per- 
pendicular to the polarization. Square etching patterns were observed only on the negative polar surface with the single domain.

5) Optical absorption measurement was done for the crystal $(x=0.2)$.

Two absorptions take place at $5.5 \mu \mathrm{m}$ and 6.5 $\mu \mathrm{m}$.

6) As is apparent from the result of chemical analysis, any ideal packing condition could not be formed. From this, it is known that the crystal is a compound with a vacancy.

\section{Acknowledgements}

The authors wish to thank Messrs K. Homma, T. Sugai, N. Sakagami for many valuable discussions and M. Aihara for help in the $\mathrm{x}$-ray diffractions and $\mathrm{T}$.
Kooda for help in the optical measurement, Research Institute of Electrical Communication, Tohoku University and M. Osagawa for help in chemical analysis, Hoya Glass Works.

\section{References}

1) E.A. Giess, B.A. Scott, B.L. Olson, G. Burns, D.F. O'Kane, J. Am. Ceram. Soc. 53, 14 (1970).

2) E.A. Giess, B.A. Scott, D.F. O'Kane, B.L. Olson, G. Burns, A.W. Smith, Mat. Res. Bull. 4 (1969).

3) S. Singh, D.A. Draegert, J.E. Geusic, Phys. Rev. B 7, 2709 (1970).

4) P.B. Jamieson, S.C. Abrahams, J. Bernstein, J. Chem. Phys. 50, 4353 (1969).

5) S.C. Abrahams, S.K. Kurtz, P.B. Jamieson, Phys. Rev., 172, 551 (1968).

[Received January 11, 1974]

\title{
タングステンブロンズ型 $\mathrm{Ba}_{2} \mathrm{Na}_{1-x} \mathrm{Li}_{x} \mathrm{Nb}_{5} \mathrm{O}_{15}$ 化合物の単結晶育成と強誘電的性質
}

\author{
增田陽一郎・和 田 正 信* \\ (八戸工業大学 電気工学科, *東北大学 工学部)
}

\begin{abstract}
タングステンブロンズ型 $\mathrm{Ba}_{2} \mathrm{Na}_{1-x} \mathrm{Li}_{x} \mathrm{Nb}_{5} \mathrm{O}_{15}$ 采化合 物の二, 三の組成 $(x=0,0.2,0.4)$ 亿ついて, 熔融法 で結晶育成を試みた. 特に $x=0.2$ の組成では (001) 面を自然面に持つ一辺 10 20 mm の透明結晶が得られ た. 室温 $\left(25^{\circ} \mathrm{C}\right)$ での格子常数はそれぞれ $a_{0}=17.473$ $\AA, b_{0}=17.480 \AA, c_{0}=9.503 \AA$ であった. Curie 点は $490^{\circ} \mathrm{C}$ に存在し, 室温での誘電率はそれぞれ $\varepsilon_{33}{ }^{T}=60$, $\varepsilon_{11}{ }^{T}=180$ を示し, Curie 点でのそれは $\varepsilon_{33}{ }^{T}=1500, \varepsilon_{11}{ }^{T}$ =360 であった. $50 \mathrm{~Hz}$ の Sowyer-Tower 回路から求
\end{abstract} めた室温での残留分極值 $P_{r 3}=2.3 \mu \mathrm{C} / \mathrm{cm}^{2}$, 抗電力 $E_{c 3}$ $=1400 \mathrm{~V} / \mathrm{mm}$ であった. $105^{\circ} \mathrm{C}$ では $P_{r 3}=21 \mu \mathrm{C} / \mathrm{cm}^{2}$, $E_{c 3}=640 \mathrm{~V} / \mathrm{mm}$ を示した. 偏光顕微鏡下での強誘電的 $180^{\circ}$ 分域の観察を行い, あわせて, エッチングピットの 観察から分域の正端および負端の関係について検討を加 えた. また化学分析を行い, 化合物の充填組成量と結晶 組成量との関倸についても検討を試みた。

$(1 / 11 / 1974$ 受付) 